\title{
A Role for Adenosine A1 Receptors in GABA and NMDA-Receptor Mediated Modulation of Dopamine Release: Studies Using Fast Cyclic Voltammetry
}

\author{
John J. O'Connor * and Carmel O’Neill \\ UCD School of Biomolecular and Biomedical Science, UCD Conway Institute of Biomolecular \& \\ Biomedical Research, University College Dublin, Belfield, Dublin 4, Ireland \\ * Author to whom correspondence should be addressed; E-mail: john.oconnor@ucd.ie
}

Received: 16 June 2008; in revised form: 1 September 2008 / Accepted: 2 September 2008 /

Published: 5 September 2008

\begin{abstract}
In the striatum many neurotransmitters including GABA, glutamate, acetylcholine, dopamine, nitric oxide and adenosine interact to regulate synaptic transmission. Dopamine release in the striatum is regulated by a number of pre- and postsynaptic receptors including adenosine. We have recently shown using isolated rat striatal slices, and the technique of fast cyclic voltammetry, that adenosine $\mathrm{A}_{1}$ receptor-mediated inhibition of dopamine release is modulated by dopamine $\mathrm{D}_{1}$ receptors. In the present study we have investigated the influence of NMDA and GABA receptor activation on the modulation of electrically stimulated dopamine release by adenosine. Application of the adenosine $\mathrm{A}_{1}$ receptor agonist, $\mathrm{N}^{6}$-cyclopentyladenosine (CPA), concentration-dependently inhibited dopamine release to a maxiumum of $50 \%$. Perfusion of the glutamate receptor agonist, NMDA, in low magnesium, caused a rapid and concentration-dependent inhibition of dopamine release. Prior perfusion with the adenosine $\mathrm{A}_{1}$ receptor antagonist, DPCPX, significantly reduced the effect of $5 \mu \mathrm{M}$ and $10 \mu \mathrm{M}$ NMDA on dopamine release. The $\mathrm{GABA}_{\mathrm{A}}$ receptor agonist, isoguvacine, had a significant concentration-dependent inhibitory effect on dopamine release which was reversed by prior application of the $\mathrm{GABA}_{\mathrm{A}}$ receptor antagonist, picrotoxin, but not DPCPX. Finally inhibition of dopamine release by CPA $(1 \mu \mathrm{M})$ was significantly enhanced by prior perfusion with picrotoxin. These data demonstrate an important role for GABA, NMDA and adenosine in the modulation of dopamine release.
\end{abstract}


Keywords: Fast cyclic voltammetry, Adenosine, GABA, NMDA, dorsolateral striatum

\section{Introduction}

The striatum receives many synaptic inputs from many different sources. Glutamatergic afferents arrive from many areas of the cortex and the thalamus, whereas the nigrostriatal pathway and other intrinsic circuits provide the striatum with acetylcholine, GABA, dopamine, nitric oxide and adenosine [1]. All these neurotransmitter systems interact with each other and with voltage-dependent conductances to regulate the efficacy of synaptic transmission within the striatum [2]. Complex interations have now been clearly shown for adenosine $A_{1} \&$ dopamine $D_{1}$ and adenosine $A_{2} \&$ dopamine $\mathrm{D}_{2}$ receptors in the striatum (for full discussions see, for example, [3-8]). We and others have shown that adenosine $A_{1}$ receptor activation in the rat striatum both in vivo [9-12] and in vitro [13-17] inhibits dopamine release in a concentration dependent manner. This inhibitory effect is reduced by pre-perfusion with the $\mathrm{D}_{1}$ receptor antagonist $\mathrm{SCH}$ 23390. Taken together, this data supports the existence of a direct inhibitory modulation of striatal dopamine release by $\mathrm{A}_{1}$ receptors and given the lack of anatomical evidence for $D_{1}$-like receptors on dopaminergic terminals [18] an indirect inhibitory modulation of striatal dopamine release by $\mathrm{D}_{1}$-like receptors through feedback loops involving other neurotransmitters.

Dopamine-glutamate reciprocal modulations play a major integrative role in the striatum. Glutamate acts on two types of glutamatergic receptors, ionotropic glutamatergic receptors (NMDA, AMPA and kainate) and metabotropic glutamatergic receptors that are G-protein coupled. Ionotropic NMDA receptors are found postsynaptically on GABA neurons [19]. These receptors are also expressed presynaptically on dopaminergic terminals [20]. NMDA receptor activation has been shown to enhance stimulated dopamine release in slice preparations. This facilitating action was reversed by NMDA receptor antagonists and was resistant to TTX, indicating that the receptors being activated are presynaptically located [21, 22]. In contrast, previous voltammetric studies have shown that the activation of NMDA receptors inhibits dopamine release [23, 24]. Thus it seems that NMDA receptor activation can have both a facilitatory and inhibitory effect on dopaminergic transmission. Conversely dopamine has also been shown to modulate glutamate release. Dopamine $\mathrm{D}_{2}$-like receptors are involved in the presynaptic inhibition of glutamatergic transmission [25]. The general consensus is that the receptors involved in the control of glutamate release throughout the striatum belong to the $\mathrm{D}_{2}$-like [26], but not the $\mathrm{D}_{1}$-like receptor family. The presence and the function of $\mathrm{D}_{1}$-like receptors on corticostriatal terminals is still a matter of some debate. $\mathrm{A}_{1}$ receptors located on corticostriatal terminals inhibit transmitter release through the blockade of $\mathrm{Ca}^{2+}$ currents [27]. As $\mathrm{A}_{1}$ receptors are located on glutamatergic terminals, it has been suggested that the ability of $\mathrm{A}_{1}$ receptors to modulate dopamine release is secondary to their ability to decrease glutamate release, resulting in a decrease in the activation of ionotropic glutamate receptors localized in dopaminergic terminals [12]. In the first section of the present study we investigate the role that NMDA receptor activation plays in the modulation of dopamine release and the influence of adenosine $\mathrm{A}_{1}$ receptors in this modulation.

GABA plays a central role in the processing of information in the striatum. There are two neuronal sources of GABA in the striatum, spiny projection neurons and intrinsic GABAergic interneurons. The 
spiny projection neurons are the prinicipal efferent cells of the striatum. These neurons receive excitatory input from motor cortices and thalamus and dopamine input from midbrain dopamine cells. Dopaminergic input is critical for the control of movement by the basal ganglia; its loss leads to the motor deficits observed in Parkinson's disease. Dopamine $\mathrm{D}_{1}$-like receptors are present on striatonigral medium spiny output GABAergic neurons. Conversely striato-pallidal GABAergic output neurons express $D_{2}$-like receptors $[28,29]$. Localization of $D_{2}$ and $D_{5}$ receptors has also been demonstrated on GABAergic interneurons [1]. Dopamine enhances GABA release [30] and $\mathrm{D}_{1}$-like receptors have been implicated in this effect [31-33]. Evidence about the effect of GABA on dopamine transmission is conflicting. In vitro studies using fast cyclic voltammetry suggest that GABA enhances dopamine release, as blockade of striatal $\mathrm{GABA}_{\mathrm{A}}$ receptors with picrotoxin caused a decrease in evoked dopamine release [34]. Other studies have also shown that GABA potentiates potassium stimulated ${ }^{3} \mathrm{H}$-dopamine release from striatal slices but did not alter spontaneous release [35]. However other in vitro studies suggest that GABA inhibits dopamine release [36-38]. In vivo studies have shown that perfusion of picrotoxin directly into the caudate nucleus, resulted in an increase in dopamine release [39]. Adenosine $A_{1}$ receptors have been reported to be present on GABAergic terminals, where $A_{1}$ receptor activation has been shown to be inhibitory [40]. With this in mind, the effect of GABA and adenosine receptor activity on dopamine release was also investigated.

\section{Experimental Section}

\subsection{Brain slices}

Male Wistar rats (50-75g) were killed by decapitation. The brain was quickly removed into ice-cold artifical cerebrospinal fluid (aCSF). Blocks of tissue containing the caudate putamen and nucleus accumbens were prepared. $350 \mu \mathrm{m}$ thick slices were sectioned using a Campden vibrotome. Brain slices were then transferred to a holding chamber containing aCSF (see below) at room temperature $\left(20-21^{\circ} \mathrm{C}\right)$ to equilibrate for $1 \mathrm{~h}$. A single slice was then transferred to a recording chamber and perfused with oxygenated aCSF at $5 \mathrm{ml} \cdot \mathrm{min}^{-1}$ at $30^{\circ} \mathrm{C}$ for $1 \mathrm{~h}$ before electrical stimulation.

\subsection{Measurement of endogenous dopamine release}

Following $1 \mathrm{~h}$ equilibration, a bipolar tungsten-stimulating electrode with a tip separation of 200 $\mu \mathrm{m}$ (A-M Systems, Inc.) was placed in the dorsolateral $\mathrm{CPu}$ (see figure 1). A carbon fibre electrode (CFE; $7 \mu \mathrm{m}$ diameter carbon fibre; 50-100 $\mu \mathrm{m}$ exposed length) was placed 100-200 $\mu \mathrm{m}$ from the stimulating electrode. In these set of experiments we manufactured the CFEs by hand and mechanically broke back the fibre to 50 - $100 \mu \mathrm{m}$ from the glass seal (by a fine forceps) rather than spark etch the eletrodes (see reference [41] for more details on carbon fibre manufacture). Fast cyclic voltammetry (FCV; Millar Voltammeter; Dr. Julian Millar, Queen Mary \& Westfield College, University of London, UK) at the CFE was used to detect changes in extracellular concentrations of dopamine following electrical stimulation of the brain slice [17, 42]. A triphasic voltage waveform (ranging from -1 to $+1.4 \mathrm{~V} ; 20 \mathrm{~ms}$ duration), generated using a Millar voltammeter [43] was applied to the CFE at $2 \mathrm{~Hz}$ (every $500 \mathrm{~ms}$; figure 2A). A sample and hold device built into the Millar 
voltammetry monitored dopamine release at $+610 \mathrm{mV}$ during each scan (figure $2 \mathrm{~B}, \mathrm{C}$; [44]. Stimulated dopamine release (using Neurolog modules) was evoked using a square-wave pulse of $10 \mathrm{~V}$ amplitude and $0.1 \mathrm{~ms}$ duration delivered once every $5 \mathrm{~min}$. A sample and hold output before during and after a stimulus is shown in figure 2D. Dopamine release under these conditions is tetrodotoxin-sensitive and $\mathrm{Ca}^{2+}$-dependent $[42,45]$. Working voltage, faradiac current and sample and hold data was recorded onto a PC via a 4 channel MacLab.

\section{Figure 1. Placement of electrodes}

Schematic diagram illustrating the placement of the carbon fibre microelectrode (recording electrode) and the bipolar stimulating electrodes (tip separation $200 \mu \mathrm{m}$ ) in the dorsolateral striatum. The carbon fibre electrode was placed 100 to $200 \mu \mathrm{m}$ from the bipolar stimulating electrodes.

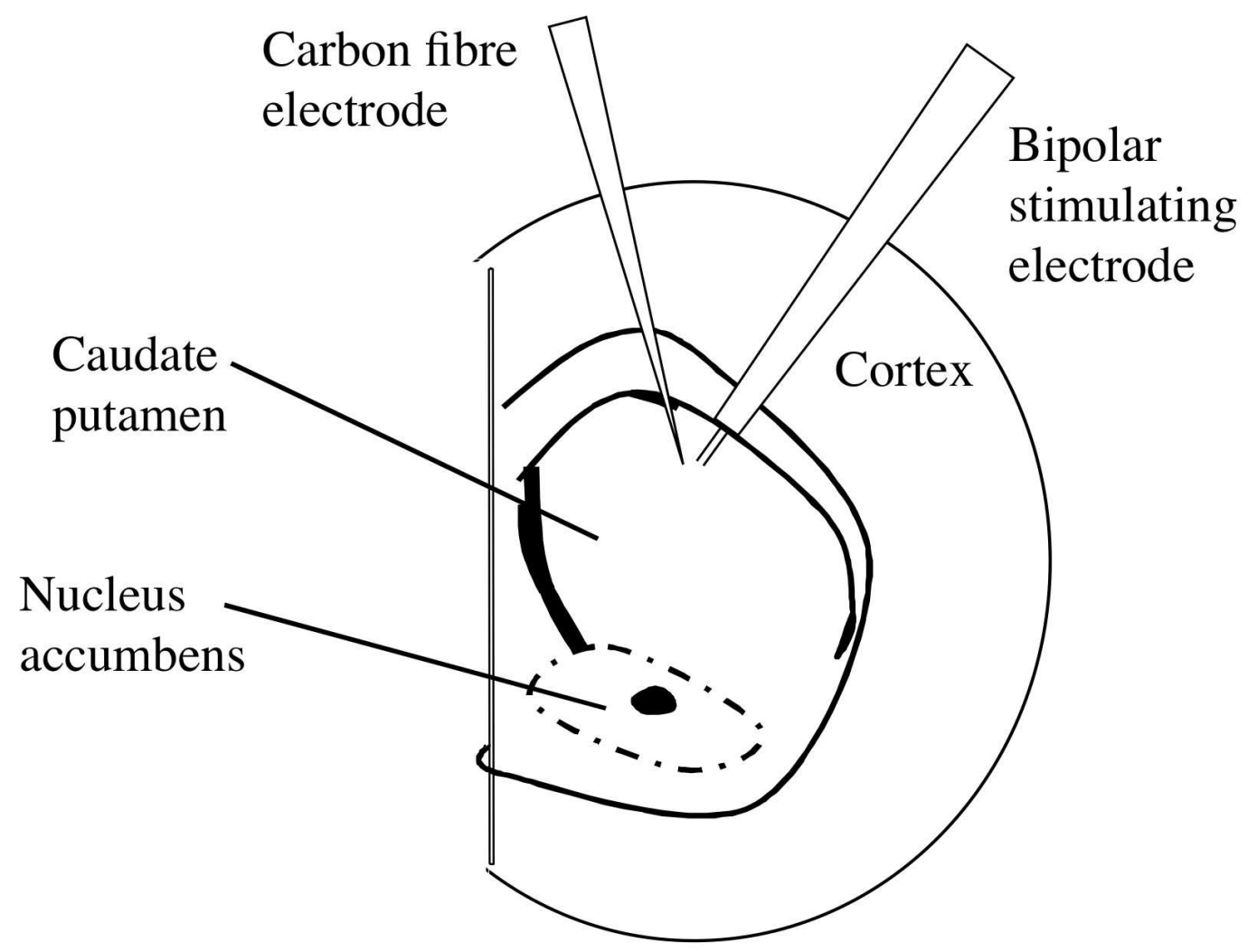

\subsection{Electrode calibration}

A typical sample and hold trace $(+610 \mathrm{mV})$ obtained during the calibration of a carbon fibre electrode is shown in figure $3 \mathrm{~A}$. Electrodes were calibrated with increasing concentrations of freshly prepared dopamine in the range $0.05 \mu \mathrm{M}$ to $1 \mu \mathrm{M}$, concentrations in the range of the endogenous dopamine released in the slices. An average standard calibration curve $(n=20)$ in shown in figure $3 B$ where the relationship of the dopamine concentration $(\mu \mathrm{M})$ and the measured faradaic current $(\mathrm{nA})$ was found to be linear in this range $\left(r^{2}=0.9952\right.$, linear correlation analysis $)$. 
Figure 2. Waveforms used in FCV

A. A triphasic voltage ramp is passed down the carbon fibre electrode twice per second ( $2 \mathrm{~Hz}$ ). The ramp sweeps from $0 \mathrm{~V}$ (relative to silver/silver chloride reference electrode) to $-1.0 \mathrm{~V}$ to $+1.4 \mathrm{~V}$ to $-1.0 \mathrm{~V}$ and back to $0 \mathrm{~V}$. This sweep lasts $20 \mathrm{~ms}$.

B. The resultant current measured by the carbon fibre electrode in called the charging current. Superimposed on the charging current is the current obtained when the electrode is placed in a ringer solution containing $1 \mu \mathrm{M}$ dopamine.

C. If the charging current in B in the absence of dopamine is subtracted from that current in the presence of dopamine a trace typical of $\mathrm{C}$ is the result (subtractogram). This is known as the faradaic current and is the result of the oxidation and reduction of dopamine on the surface of the carbon fibre electrode. Dopamine oxidizes at approximately $+610 \mathrm{mV}$ and is reduced at approximately $-200 \mathrm{mV}$.

D. The trace illustrated in $D$ is the result of a sample and hold device measuring at +610 $\mathrm{mV}$ during the electrical stimulation of the striatum. The arrow indicates the time of stimulation of striatum $(0.1 \mathrm{~ms}$ pulse width; $10 \mathrm{~V})$. Post calibration of the CFMe indicated that approximately $0.1 \mu \mathrm{M}$ dopamine is evoked by a single electrical stimulation in the dorsolateral striatum. Peak rise time is approximately $1 \mathrm{~s}$ and half decay time approximately $1.5 \mathrm{~s}$.
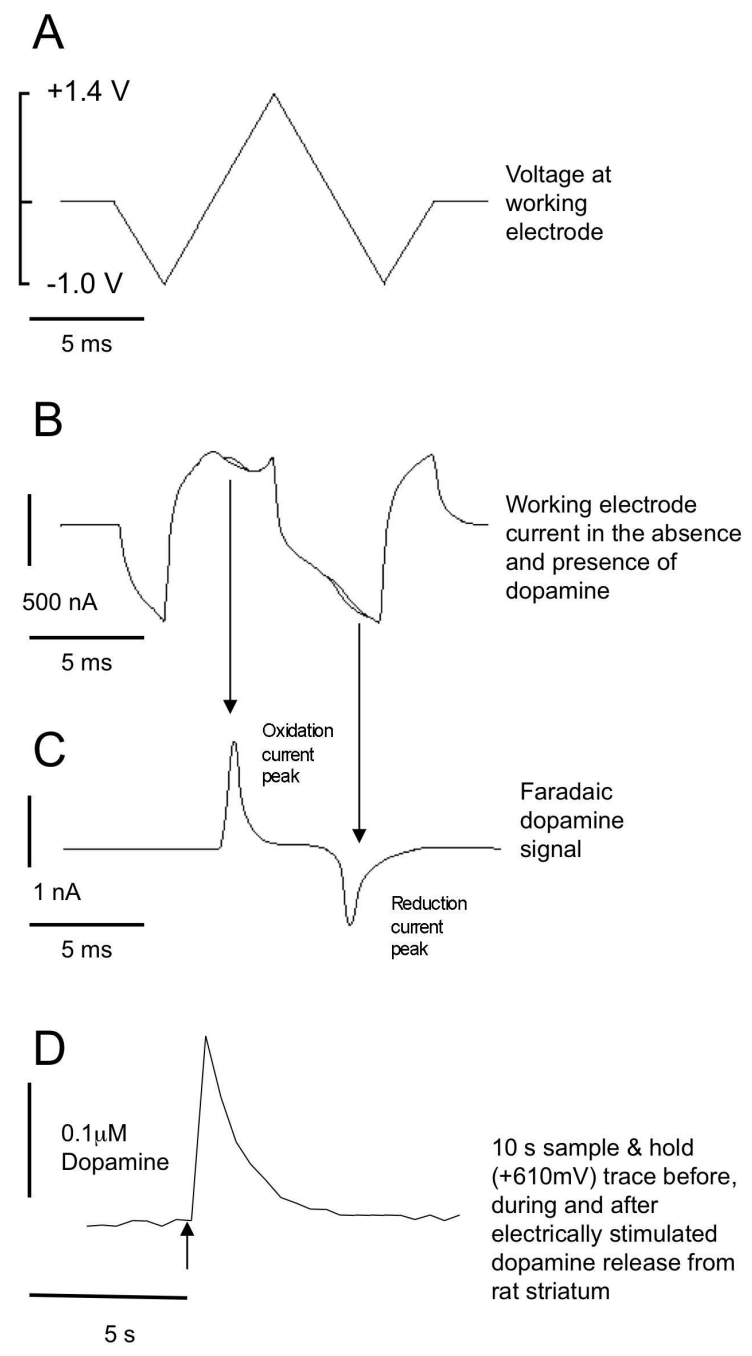
Figure 3. Calibration of the carbon fibre electrode

Carbon fibre electrodes were routinely placed in known concentrations of freshly prepared dopamine after experiments in brain slices. A. Typical sample and hold output from an electrode after cumulative concentrations of dopamine were added ( 0.05 to 1 $\mu \mathrm{M})$. The concentrations used are within the range of dopamine levels measured upon electrical stimulation in the striatum. B. Calibration curve showing the average of 20 carbon fibre electrodes. The relationship between dopamine concentration at the surface of the electrode and the measured current was found to be linear at these concentrations $\left(r^{2}=0.9952\right)$.
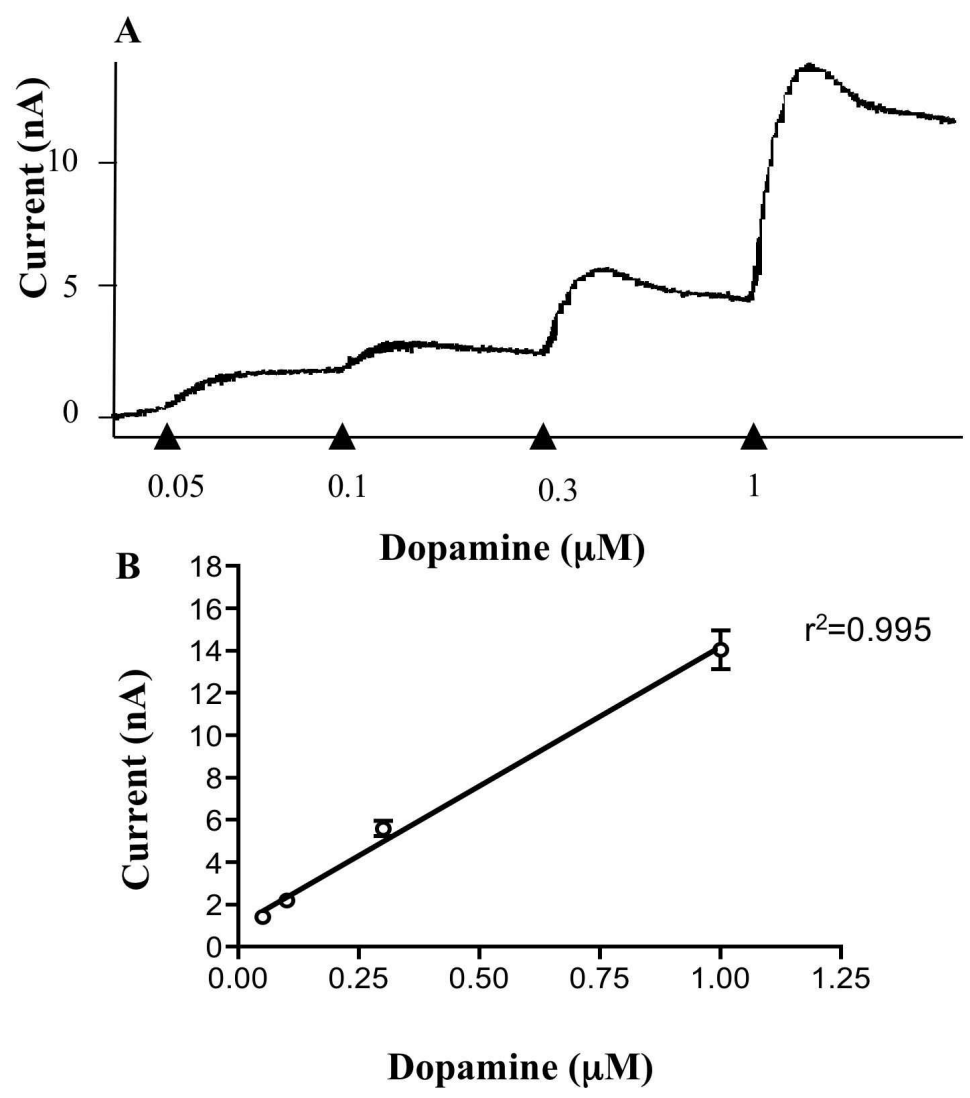

\subsection{Buffers and Drugs}

Artificial cerebrospinal fluid (aCSF) was prepared every day according to the following composition in $\mathrm{mM}$ : $\mathrm{NaCl}, 120 ; \mathrm{KCl}, 2.5 ; \mathrm{MgSO}_{4}, 2 ; \mathrm{CaCl}_{2}, 2 ; \mathrm{NaH}_{2} \mathrm{PO}_{4}, 1.25$ and D-glucose, $10 \mathrm{mM}$ in $\mathrm{H}_{2} \mathrm{O}$. aCSF was bubled with $95 \% \quad \mathrm{O}_{2} / 5 \% \quad \mathrm{CO}_{2} . \mathrm{N}^{6}$-cyclopentyladenosine (CPA), isoguvacine hydrochloride, and metoclopramide monohydrochloride, were obtained from Sigma, UK and dissolved in de-ionized water. 8-cyclopentyl-1,3-dipropylxanthine (DPCPX; Tocris Cookson, UK) and picrotoxin (Sigma, UK) were dissolved in dimethylsulphoxide (DMSO). Stock solutions of DMSO were made to obtain concentrations of DMSO lower than $0.005 \%$ in the superfusing aCSF. Control experiments for solvent were carried out in parallel. This final concentration of DMSO $(0.005 \%)$ in the perfusing aCSF did not affect single pulse dopamine release, rise time or decay time (figure 4C). NMDA and GBR12909 (both Tocris Cookson, UK) were dissolved in de-ionized water. All drugs 
were made up to stock solutions, which were stored at $-80^{\circ} \mathrm{C}$. All drugs were maintained in the perfusion medium for the entire duration of each experiment. All control experiments were carried out intermittently between drug experiments. In pre-treatment experiments drugs were pre applied for either 30 or $60 \mathrm{~min}$.

\subsection{Data analysis}

Single pulse evoked dopamine over flow was measured as the peak release in response to electrical stimulation (figure 4). Rise time and half decay time of dopamine release were measured in some of the experiments. Rise time was measured from the beginning of baseline to peak amplitude and half decay time was measured from peak release to $50 \%$ half decay (see figure 4A). Stimulated dopamine release was measured for $20 \mathrm{~min}$ (4 stimulations) prior to drug application and the average of these 4 values were taken as $100 \%$. All values subsequent to these were represented as \% control. All data was analysed using the GraphPad Prism, version 4.00 (GraphPad Software Inc. 2003) statistical analysis platforms. Data are presented as means \pm standard error of the mean (sem) of $\mathrm{n}$ independent experiments (different brain slices). Students t-test (paired and unpaired sampling where appropriate) was used where $\mathrm{P}<0.05$ was considered significant. In figure 7 one-way ANOVA was used to compare data from the different concentrations of isoguvacine to those in the presence of DCPCX.

\section{Results}

\subsection{Effect of low magnesium on single pulse evoked dopamine release}

Under normal physiological conditions, NMDA receptors are blocked by $\mathrm{Mg}^{2+}$ ions. To unmask the NMDA effect on dopamine transmission, experiments were carried out using low $\mathrm{Mg}^{2+} \mathrm{aCSF}(0.3 \mathrm{mM}$ $\mathrm{Mg}^{2+}$ ). The rise time of single pulse evoked dopamine release was not significantly affected by perfusion with low $\mathrm{Mg}^{2+}$ aCSF (figure 4B (first trace) and C). Also the half decay time of the dopamine signal did not differ significantly from controls. As a comparison to these data we also tested the dopamine $D_{2}$ receptor antagonist, metoclopramide, which is know to affect multiple pulse dopamine release but not single pulse (see reference [46]) and GBR12909, the dopamine reuptake inhibitor. Metoclopramide had no effect on rise time or half decay time. However as expected GBR 12909 caused a 300\% increase in rise time and a 450\% increase in half decay time (figure 4B and C).

\subsection{Role of $A_{1}$ receptors in the NMDA modulation of dopamine release}

Perfusion with NMDA $(5,10$ and $20 \mu \mathrm{M})$ in low $\mathrm{Mg}^{2}$ caused a concentration dependent reduction of single pulse evoked dopamine release (control, 91.7 $55.3 \% ; 5 \mu \mathrm{M}$ NMDA, $75.4 \pm 4.9 \% ; 10 \mu \mathrm{M}$ NMDA 3.6 $\pm 3.1 \% ; 20 \mu \mathrm{M}$ NMDA, 0\%; $\mathrm{n}=6-7$; all at $60 \mathrm{~min}$; figure 5A and B). Dopamine release was unaffected by perfusion with $1 \mu \mathrm{M}$ DPCPX for $60 \mathrm{~min}(\mathrm{n}=6)$. Pre-perfusion with DPCPX partially but significantly attenuated the inhibitory effect of both 5 and $10 \mu \mathrm{M}$ NMDA on dopamine release (83.9 \pm 3.4 versus $75.4 \pm 4.9 \%$ and $9.8 \pm 3.6 \%$ versus $3.6 \pm 3.1 \% ; n=6, P<0.05$ for both; figure $5 \mathrm{~B}$ ). 
Figure 4. Effect of low $\mathrm{Mg}^{2+}$, metoclopramide and GBR12909 on single pulse evoked dopamine release

Single pulse evoked dopamine release was measured as the peak release in response to electrical stimulation.

A. Rise time was measured from the beginning of the baseline to peak amplitude and half decay time was measured from peak release to $50 \%$ half decay. Dot indicates point of stimulation.

B. Sample traces showing control stimulated dopamine release (black) and superimposed traces (all red) obtained after 30 min perfusion with $0.3 \mathrm{mM} \mathrm{Mg}^{2+}$ (left), $0.3 \mu \mathrm{m}$ metoclopramde (centre) and $3 \mu \mathrm{M}$ GBR12909 (right). Whilst low $\mathrm{Mg}^{2+}$ and metoclopramide have no effect on single pulse release, GBR12909 has a dramatic affect.

C. Summary of the effects shown in $\mathrm{B}(* \mathrm{P}<0.05)$.

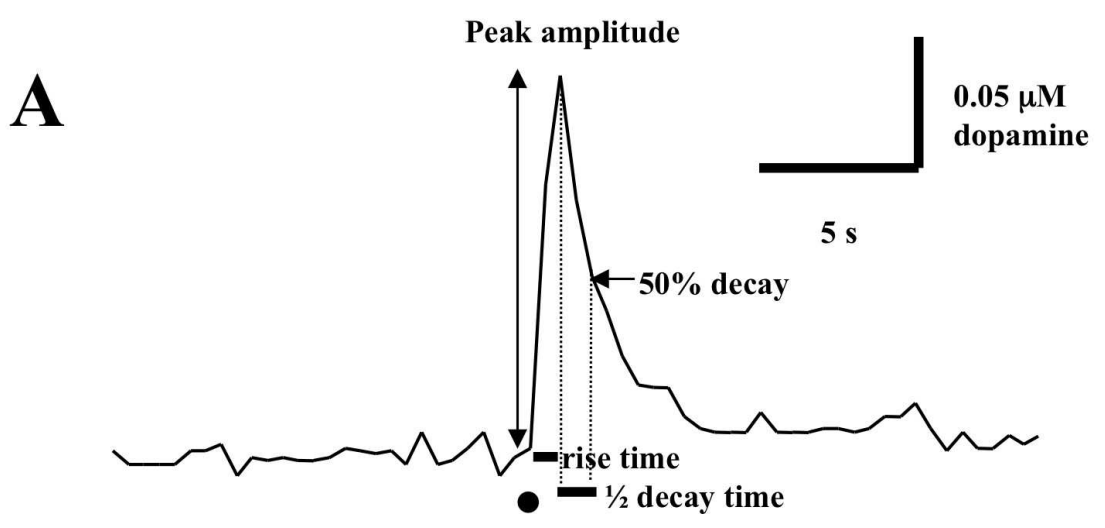

Stimulus

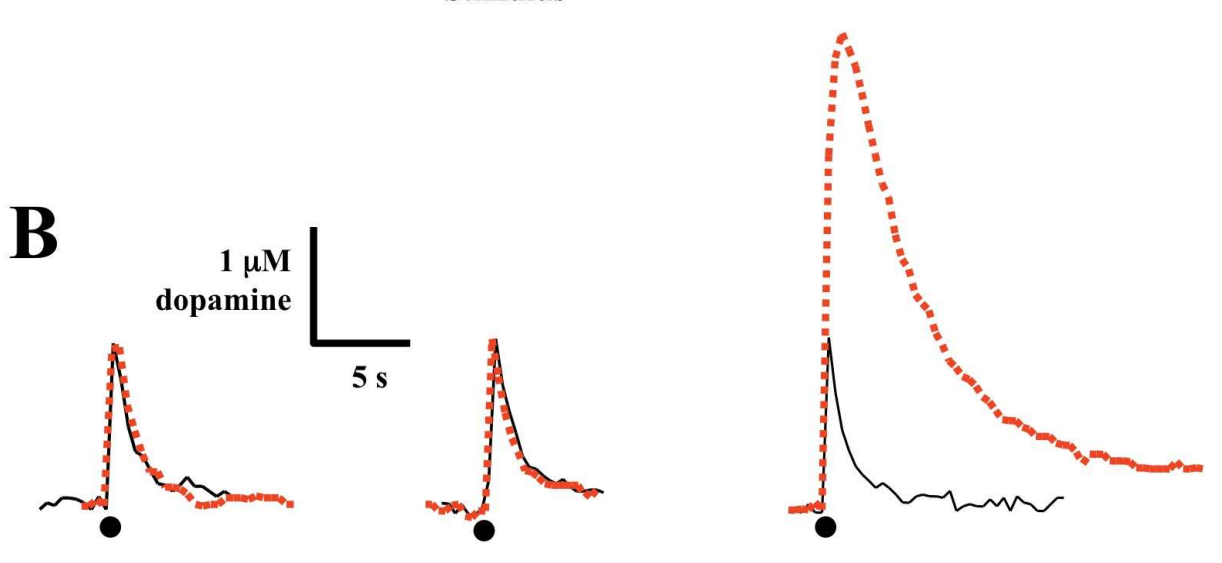

\begin{tabular}{|l|c|c|}
\hline \multicolumn{1}{|c|}{$(\mathrm{n})$} & Rise time $(\mathrm{s})$ & $1 / 2$ decay time $(\mathrm{s})$ \\
\hline Control (13) & 0.5 to 1.0 & 1.0 to 1.5 \\
\hline DMSO $(0.005 \%)(4)$ & 0.5 to 1.0 & 1.0 to 1.5 \\
\hline $0.3 \mathrm{mM} \mathrm{Mg++} \mathrm{(5)}$ & 0.5 to 1.0 & 1.0 to 1.5 \\
\hline Metoclopramide (3) & 0.5 to 1.0 & 1.0 to 1.5 \\
\hline GBR12909 (3) & 3.0 to $3.5^{*}$ & 6.0 to $7.0^{*}$ \\
\hline
\end{tabular}


Figure 5. Effect of NMDA and DPCPX on single pulse evoked dopamine release

A. Typical sample and hold data traces, showing the effects of three concentrations of NMDA on single pulse evoked dopamine release. Single pulse stimulation was applied at 5 min intervals. All experiments where carried out using low $\mathrm{Mg}^{2+}(0.3 \mathrm{mM}$ in the aCSF). Perfusion with 5, 10 and $20 \mu \mathrm{M}$ NMDA caused a concentration dependent inhibition of dopamine release. Perfusion with $20 \mu \mathrm{M}$ NMDA caused a near complete inhibition of dopamine release in 5 out of 5 experiments.

B. Summary graphs showing the effect of DCPCX $(1 \mu \mathrm{M})$ on the inhibition of dopamine release by 5, 10 and $20 \mu \mathrm{M}$ NMDA. Prior perfusion with DPCPX for $30 \mathrm{~min}$ before the application NMDA significantly attenuated the effects of 5 and $10 \mu \mathrm{M}$ NMDA but not that of $20 \mu \mathrm{M}$ NMDA ( ${ }^{*} \mathrm{P}<0.05$; see text for details).

A
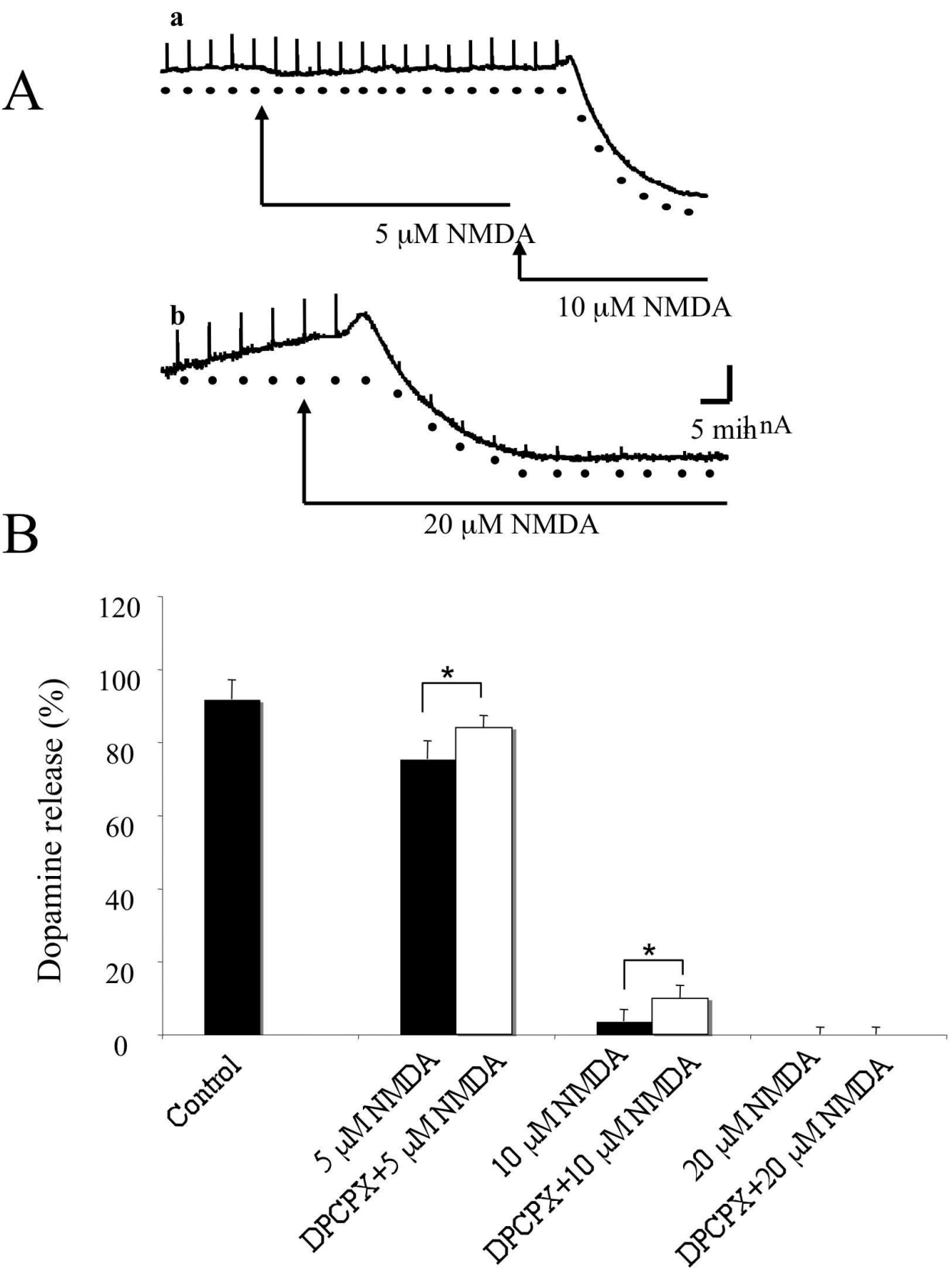
3.3 Role of the $G A B A_{A}$ receptor antagonist picrotoxin, in the CPA-induced inhibition of dopamine release

Perfusion with picrotoxin $(100 \mu \mathrm{M})$ for $60 \mathrm{~min}$ did not alter single pulse evoked dopamine release (control, 91.6 $\pm 2.3 \%, \mathrm{n}=13$ versus picrotoxin, 83.5 $\pm 3.9 \%, \mathrm{n}=5, \mathrm{P}>0.05$ ). This may imply that $\mathrm{GABA}_{\mathrm{A}}$ receptors do not tonically modulate dopamine transmission, at least in the in vitro preparation. Addition of the adenosine $\mathrm{A}_{1}$ receptor agonist, CPA at $1 \mu \mathrm{M}$ (this concentration has previously been shown to cause moderate inhibitory effects on dopamine release [17]) caused a small but significant reduction in dopamine release compared to control values $(79.3 \pm 5.8 \%, \mathrm{n}=6, \mathrm{P}<0.05)$. However the inhibition of dopamine release by CPA was significantly enhanced by prior perfusion with picrotoxin for $30 \mathrm{~min}$ before the addition of CPA $(53.1 \pm 7.2 \%, \mathrm{n}=6, \mathrm{P}<0.01$; figure $6 \mathrm{~A})$. Perfusing the slice with a higher concentration of CPA $(30 \mu \mathrm{M}$; previously shown to cause near maximal effects on dopamine release, [17]) for $60 \mathrm{~min}$ also caused a significant reduction in dopamine release (control, 92 $\pm 2.3 \%$, $\mathrm{n}=13$ versus $30 \mu \mathrm{M}$ CPA $66.5 \pm 3.3 \%, \mathrm{n}=5, \mathrm{P}<0.001$; figure $6 \mathrm{~B}$ ). However prior perfusion with picrotoxin $(100 \mu \mathrm{M})$ for 30 minutes did not significantly increase this inhibitory effect of $30 \mu \mathrm{M} \mathrm{CPA}$ on dopamine release $(63.8 \pm 4.5 \%, \mathrm{n}=5, \mathrm{P}>0.05)$. Indeed a maximum inhibitory effect may already have been reached at this concentration of CPA (see reference [17]).

3.4 Role of the $G A B A_{A}$ receptor agonist, isoguvacine and the $A_{1}$ receptor antagonist DPCPX in dopamine release.

Perfusion of cumulative concentrations of isoguvacine (1, 10, 30 and $100 \mu \mathrm{M}$ ), the selective $\mathrm{GABA}_{\mathrm{A}}$ receptor agonist, inhibited dopamine release in a concentration dependent manner. Results are expressed as dopamine release versus the log concentration of isoguvacine in figure 7A. Perfusion with 1 or $10 \mu \mathrm{M}$ isoguvacine did not significantly reduce dopamine release (e.g. control, $99.1 \pm 3.3 \%, \mathrm{n}=7$; $10 \mu \mathrm{M}$ isoguvacine, 86.4 $\pm 2.8, \mathrm{n}=5$; $\mathrm{P}>0.05$ ). However perfusion with 30 or $100 \mu \mathrm{M}$ isoguvacine, for 30 min significantly inhibited dopamine release $(78.8 \pm 2.1$ and $62.1 \pm 3.4 \%$, respectively; $\mathrm{n}=5, \mathrm{P}<0.05$; figure $7 \mathrm{~A})$. Prior perfusion with picrotoxin $(100 \mu \mathrm{M})$ for $30 \mathrm{~min}$ significantly reduced the inhibitory effect of 30 and $100 \mu \mathrm{M}$ isoguvacine on dopamine release (e.g. $100 \mu \mathrm{M}$ isoguvacine, $62.1 \pm 3.4 \%$ vs picrotoxin $+100 \mu \mathrm{M}$ isoguvacine, $87.4 \pm 7.6 \% \mathrm{n}=5, \mathrm{P}<0.05)$.

The role played by $A_{1}$ receptors in the inhibitory effect of isoguvacine on dopamine release was investigated. Slices were pre-perfused with the $A_{1}$ receptor antagonist, DPCPX $(1 \mu \mathrm{M})$ for $30 \mathrm{~min}$ before addition of isoguvacine. In the presence of DPCPX, the inhibitory effect of isoguvacine on dopamine release was significantly enhanced (e.g. DPCPX $+10 \mu \mathrm{M}$ isoguvacine, $75.9 \pm 3.8 \%, \mathrm{n}=5$, $\mathrm{P}<0.01$ versus controls; $\mathrm{DPCPX}+30 \mu \mathrm{M}$ isoguvacine, $70.4 \pm 4.6 \%, \mathrm{n}=5, \mathrm{P}<0.05$ versus controls; $\mathrm{DPCPX}+100 \mu \mathrm{M}$ isoguvacine, $50.8 \pm 3.1 \%, \mathrm{n}=5$. $\mathrm{P}<0.001$ versus controls). Using one way analysis of variance the inhibitory effect of isoguvacine in the presence of DPCPX on dopamine release was found to be significantly greater than treatment with isoguvacine alone $(\mathrm{F}=5.1 ; \mathrm{P}<0.05$; Figure $7 \mathrm{~B})$. 
Figure 6. Picrotoxin enhances the inhibitory effect of $1 \mu M$ CPA but not $30 \mu M$ CPA on dopamine release

A. Perfusion with $100 \mu \mathrm{M}$ picrotoxin for $60 \mathrm{~min}$ did not significantly alter electrically evoked dopamine release $(83.5 \pm 3.9 \%, \mathrm{n}=5, \mathrm{P}>0.05)$. However perfusion with $1 \mu \mathrm{M}$ CPA reduced dopamine release compared to control values $(79.3 \pm 5.8 \%, \mathrm{n}=6, \mathrm{P}>0.05)$. Prior perfusion with $100 \mu \mathrm{M}$ picrotoxin significantly enhanced the inhibitory effect of 1 $\mu \mathrm{M}$ CPA on dopamine release $(53.1 \pm 7.2 \%, \mathrm{n}=6, \mathrm{P}<0.01)$. Typical sample and hold traces are shown for controls, slices treated with $100 \mu \mathrm{M}$ picrotoxin, $1 \mu \mathrm{M} \mathrm{CPA}$ and picrotoxin+CPA. All traces were obtained 60 min after drug application. Dots indicates point of stimulation of brain slice.

B. Picrotoxin does not increase further the inhibitory effect of $30 \mu \mathrm{M} \mathrm{CPA}$ on dopamine release. Addition of $30 \mu \mathrm{M}$ CPA for 60 min significantly inhibited dopamine release (control, $92 \pm 2.3 \%, \mathrm{n}=13$ versus $30 \mu \mathrm{M} \mathrm{CPA}, 66.5 \pm 3.3 \%, \mathrm{n}=5$ ). Prior perfusion with 100 $\mu \mathrm{M}$ picrotoxin for $30 \mathrm{~min}$ did not alter the effect of CPA when compared to CPA alone $(63.8 \pm 4.5, \mathrm{n}=5)$. Typical sample and hold traces were obtained $60 \mathrm{~min}$ after drug application for control, $30 \mu \mathrm{M} \mathrm{CPA}$ and picrotoxin+CPA.

A
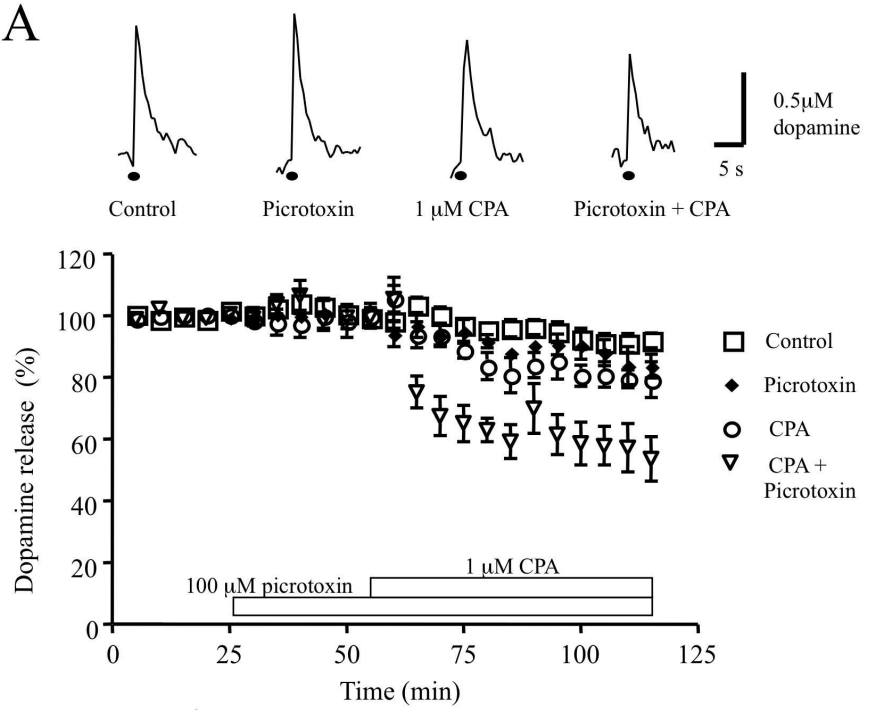

$\mathrm{B}$
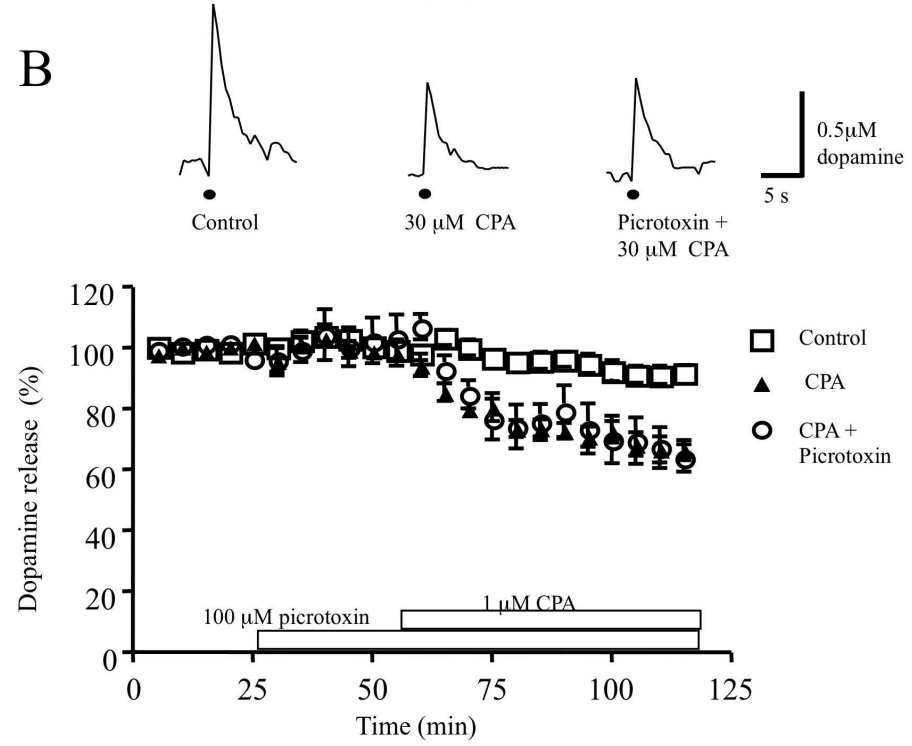
Figure 7. The inhibition of dopamine release in the rat striatum by isoguvacine is modulated by DPCPX

A Concentration response curve for the effects of isoguvacine on dopamine release. Results are expressed as dopamine release (\%), 30 minutes after perfusion with each cumulative concentrations of isoguvacine $(10,30$ and $100 \mu \mathrm{M})$, versus $\log$ concentration of isoguvacine. Isoguvacine inhibited dopamine release in a concentration-dependent manner, that reached significance $30 \mathrm{~min}$ after perfusion (e.g. control $85.2 \pm 4.9 \%, \mathrm{n}=7$ versus $100 \mu \mathrm{M}$ isoguvacine, 62.1 $\pm 3.4 \%, \mathrm{n}=5$. $\mathrm{P}<0.05$ ). Pre treatment of slices with picrotoxin reversed the inhibitory effects of $100 \mu \mathrm{M}$ isoguvacine $(100 \mu \mathrm{M}$ isoguvacine, $50.8 \pm 3.1 \%, \mathrm{n}=5$ versus picrotoxin $+100 \mu \mathrm{M}$ isoguvacine, $87.4 \pm 7.6 \%, \mathrm{n}=5, \mathrm{P}<0.05)$. Shown are typical sample and hold traces obtained under control conditions and $30 \mathrm{~min}$ after the perfusion of $10 \mu \mathrm{M}$ isoguvacine, $100 \mu \mathrm{M}$ isoguvacine and picrotoxin+isoguvacin.

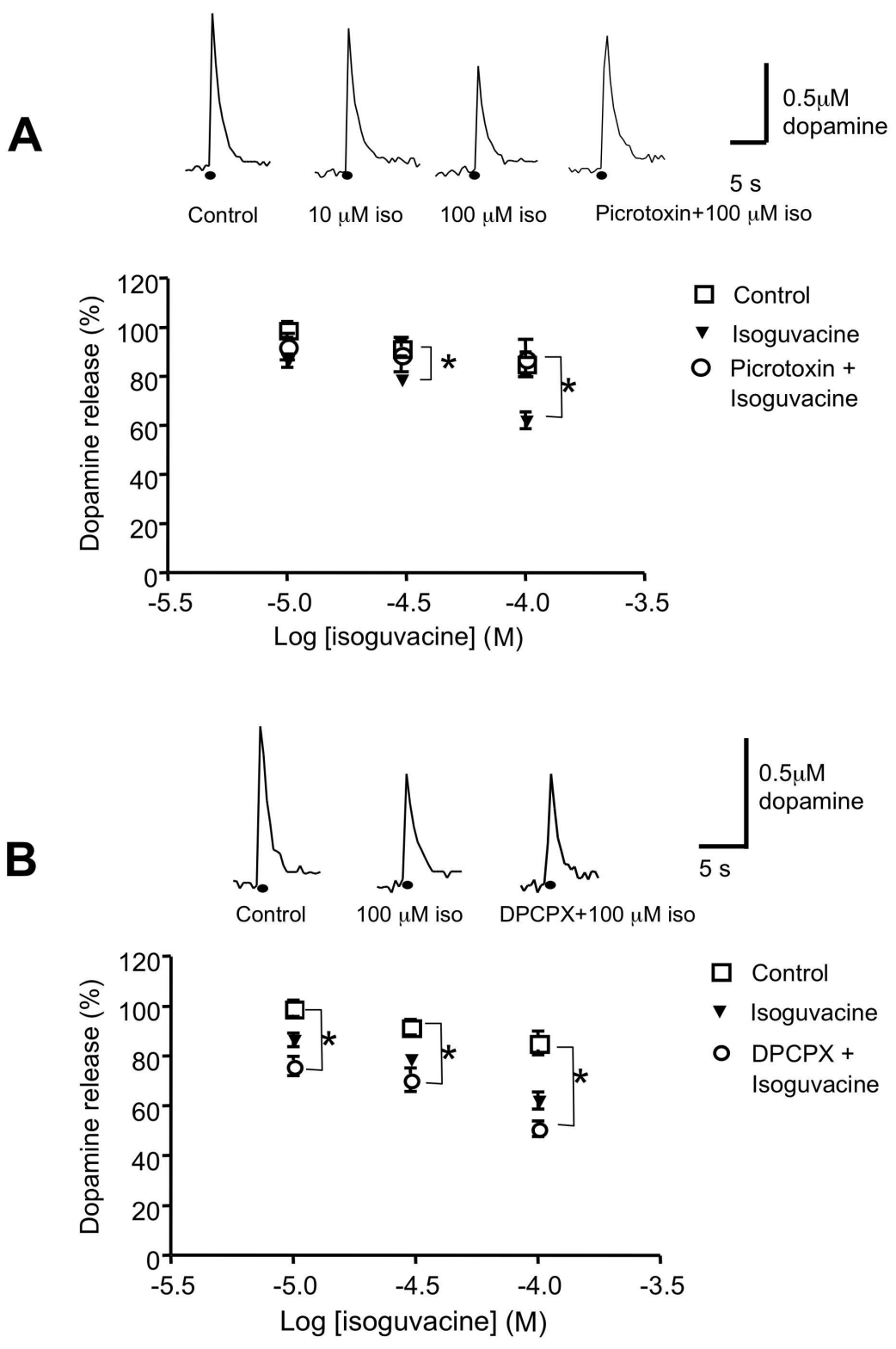


Figure 7. caption cont.

B. The inhibition of dopamine release by isoguvacine is modulated by prior application of the adenosine receptor antagonist DPCPX.

In the presence of DPCPX, isoguvacine significantly inhibited dopamine release at all concentrations compared to control values. (DPCPX $+10 \mu \mathrm{M}$ isoguvacine, $75.9 \pm 3.8 \%$, $\mathrm{n}=5, \mathrm{P}<0.01$ versus controls; DPCPX $+30 \mu \mathrm{M}$ isoguvacine, $70.4 \pm 4.6 \%, \mathrm{n}=5, \mathrm{P}<0.05$ versus controls; DPCPX $+100 \mu \mathrm{M}$ isoguvacine, 50.8 $\pm 3.1 \%, \mathrm{n}=5$. $\mathrm{P}<0.001$ versus controls). Using one-way analysis of variance these effects were found to be significantly different from treatment with isoguvacine alone $(\mathrm{P}<0.05)$. Shown are typical sample and hold traces obtained under control conditions, and $30 \mathrm{~min}$ after the perfusion of $100 \mu \mathrm{M}$ isoguvacine and DPCPX+ isoguvacine. Dots indicate point of stimulation in the slice.

\section{Discussion}

In the present studies we have shown that the inhibitory effects of NMDA on electrically stimulated dopamine release can be modulated by adenosine $\left(A_{1}\right)$ receptor block and that the inhibitory effect of adenosine $\left(\mathrm{A}_{1}\right)$ receptor activation on electrically stimulated dopamine release can be enhanced by GABA receptor block. In addition we also demonstrate a role for $\mathrm{A}_{1}$ receptors in the inhibitory effects of isoguvacine (GABA agonist) on electrically stimulated dopamine release.

\subsection{Glutamate transmission}

Electrical stimulation of the dorsal striatum releases many neurotransmitters including dopamine, glutamate, acetylcholine, adenosine and GABA. NMDA receptor activation has been shown to increase adenosine release in striatal slices [47], which in turn inhibits the release of excitatory amino acids via $A_{1}$ receptors located on glutamatergic terminals. We therefore set out to look at any possible modulation of the inhibitory effects of NMDA on dopamine release by adenosine receptor activation. As demonstrated with previous voltammetric studies $[23,24]$ we have shown that perfusion of NMDA in low $\mathrm{Mg}^{2+} \mathrm{aCSF}$, inhibited electrically evoked dopamine release. Low $\mathrm{Mg}^{2+} \mathrm{aCSF}$ alone did not alter the release and uptake kinetics of dopamine release. Single pulse evoked dopamine release was very sensitive to NMDA receptor activation. Perfusion with concentrations of NMDA of 10 and $20 \mu \mathrm{M}$ near completely abolished stimulated dopamine release. Irvani \& Kruk (1996), proposed that, activation of NMDA receptors causes a large release of dopamine, leading to a depletion of dopamine, and subsequent inhibition of electrically stimulated dopamine release. In our experiments using 10 and 20 $\mu \mathrm{M}$ NMDA, a transient increase in the charging current, followed by a decrease in the charging current was observed, as has been reported by [23], suggesting that perfusion with NMDA does alter the components that contribute to the charging current and possibe a depletion of dopamine. Application of NMDA is likely to lead to global depolarisation of the tissue an effect independent of the presence of NMDARs on dopamine axons. This would deplete the releasable pool of dopamine and give rise to the inhibition of stimulated dopamine release that we have observed. 
Pre-perfusion with $1 \mu \mathrm{M}$ DPCPX, the adenosine $\mathrm{A}_{1}$ receptor antagonist, for $30 \mathrm{~min}$ had a small but significant attenuating effect on the effects of $5 \mu \mathrm{M}$ NMDA on dopamine release. $1 \mu \mathrm{M}$ DPCPX has been previously used in studies in the nucleus accumbens [48]. Lower concentrations of 100 to $200 \mathrm{nM}$ have also been used (see for example the effects of DPCPX on synaptic plasticity in the hippocampus [49]. Pre-perfusion with DPCPX did also reduce albeit to a small degree, the large inhibitory effect, of $10 \mu \mathrm{M}$ NMDA on dopamine release. These results are hard to interpret as NMDA may be depleting neurones of dopamine. Adenosine also plays a major role in hypoxia and tissue damage in slices [50] and the attenuating efects of adenosine receptor block on the NMDA inhibition of dopamine release may involve many of these signalling mechanisms. Although adenosine does have a significant modulating role in both glutamatergic and dopaminergic transmission, in our experiments it does not seem to play a major role in the glutamatergic modulation of dopamine release.

\subsection{GABA transmission}

We next investigated a role for GABARs in the adenosine-induced inhibition of dopamine release. Perfusion with $100 \mu \mathrm{M}$ picrotoxin, at a concentration that has been used previously in brain striatal slices [45, 34], did not alter single pulse evoked dopamine release. This is in agreement with previous in vitro voltammetric experiments using GABAzine to block $\mathrm{GABA}_{\mathrm{A}}$ receptors, indicating a lack of GABAergic tone in the slice preparation [51]. In our experiments picrotoxin significantly enhanced the inhibitory effect of the lower concentration of CPA $(1 \mu \mathrm{M})$ on dopamine release but had no effect on the higher concentration of CPA $(30 \mu \mathrm{M})$. These results are surprising because, if picrotoxin was acting on $\mathrm{GABA}_{\mathrm{A}}$ receptors located on dopamine terminals one would expect an increase in dopamine release. In vivo microdialysis studies have shown that bicuculline, a $G_{A B A}$ receptor antagonist, increased striatal acetylcholine output, whereas muscimol, a $\mathrm{GABA}_{\mathrm{A}}$ receptor agonist, decreased striatal acetylcholine output [52]. It may be possible that picrotoxin is acting on $\mathrm{GABA}_{\mathrm{A}}$ receptors located on acetylcholine interneurons [53], enhancing acetylcholine release. Prior perfusion with picrotoxin did not alter the inhibitory effect of the higher concentration of CPA $(30 \mu \mathrm{M})$. Perfusion with $30 \mu \mathrm{M}$ CPA reduced dopamine release to $66.5 \pm 3 \%$, which is not significantly different to the inhibitory effect of perfusion with $100 \mu \mathrm{M} \mathrm{CPA}(56.8 \pm 10 \%$; results not shown). This may imply that perfusion with $30 \mu \mathrm{M}$ CPA elicits maximum inhibition in this system and addition of picrotoxin did not increase the maximal effect of CPA.

Perfusion with isoguvacine, the $\mathrm{GABA}_{\mathrm{A}}$ receptor agonist inhibited dopamine release in a concentration-dependent manner, which was reversed by pre-perfusing the slice with picrotoxin, suggesting that isoguvacine is acting directly via $\mathrm{GABA}_{\mathrm{A}}$ receptors to inhibit evoked dopamine release. A high concentration of isoguvacine was required to significantly inhibit dopamine release. However in vitro patch clamp studies carried out in brain slices containing the ventral tegemental area used concentrations that ranged from 10-300 $\mu \mathrm{M}$ isoguvacine and they obtained an $\mathrm{EC}_{50}$ value of $62 \pm 8$ $\mu \mathrm{M}$ isoguvacine [54]. Using the post-embedding immunogold technique on freeze-substituted tissue, Fujiyama et al., 2000 [55] were unable to rule out the presence of $\mathrm{GABA}_{\mathrm{A}}$ receptors on dopamine terminals. Also GABA activity has been shown to modulate dopamine transmission, possibly by acting through $\mathrm{GABA}_{\mathrm{A}}$ receptors on nigrostriatal dopaminergic terminals $[36,37,56]$. Dopamine $\mathrm{D}_{1}$-like receptors found on the GABAergic neurons of the direct pathway and also fast-spiking GABAergic 
interneurons, depolarize the cell membrane and enhances electrically evoked GABA release [1, 57]. The attenuation of inhibitory GABAergic tone on dopaminergic neurons results in increased dopamine release. The $\mathrm{A}_{1}$ receptor antagonist, DPCPX, enhanced the isoguvacine effect on dopamine, an effect which was significant when compared to isoguvacine alone. DPCPX may be acting on $\mathrm{A}_{1}$ receptors found on GABAergic terminals and may produce an overall increase of GABA in the synaptic cleft, thus enhancing the isoguvacine effect. $\mathrm{D}_{2}$-like receptors are located on GABAergic interneurons and striatopalidal spiny projection neurons, were they inhibit GABA release $[33,58]$. A role for $D_{2}$ receptor activation in the effects of CPA on dopamine release was ruled out, as metoclopramide has previously been shown not alter the CPA effect; see reference [17].

In the in vitro slice preparation, connectivity between different neurons is likely to be at least partially maintained. It is possible that ligands are acting on receptors other than those found on nigrostriatal terminals to modulate neurotransmitter release. These neurotransmitter systems interact with each other and with voltage-dependent conductances to regulate dopaminergic transmission. The dopamine response in our experiements is elicited by a short, discrete stimulus, so although other neurotransmitters are being released, it is unlikely that changes in neurotransmitter levels due to electrical stimultion can act on the evoked dopamine. The dopaminergic terminals contain fast acting ionotropic receptors and it is likely that the concentration of neurotransmitters in the synaptic cleft and extracellular space plays a fundamental role in determining the excitability of the dopaminergic terminal, thus determining the amount of dopamine released due to a single pulse stimulus.

\section{Conclusion}

In conclusion in our experiments using the technique of fast cyclic voltammetry, we have demonstrated a novel role for adenosine, glutamate and GABA in the modulation of dopamine release in the dorsolateral striatum.

\section{Acknowledgements}

We would like to thank the Health Education Authority (HEA) Ireland, the Program for Research in Third Level Institutes (PRTLI) Cycle 3 for funding, and Dr Zyg Kruk for advice and technical assistance with the FCV

\section{References}

1. Centonze, D.; Grande, C.; Usiello, A.; Gubellini, P.; Erbs, E.; Martin, A.B.; Pisani, A.; Tognazzi, N.; Bernardi, G.; Moratalla, R.; Borrelli, E.; Calabresi, P. Receptor subtypes involved in the presynaptic and postsynaptic actions of dopamine on striatal interneurons. J. Neurosci. 2003, 23, (15), 6245-6254.

2. Calabresi, P.; Centonze, D.; Gubellini, P.; Marfia, G.A.; Pisani, A.; Sancesario, G.; Bernardi, G. Synaptic transmission in the striatum: from plasticity to neurodegeneration. Prog. Neurobiol. 2000, 61, (3), 231-265. 
3. Ferre, S.; Popoli, P.; Gimenez-Llort, L.; Finnman, U.B.; Martinez, E.; Scotti de Carolis, A.; Fuxe, K. Postsynaptic antagonistic interaction between adenosine A1 and dopamine D1 receptors. Neuroreport 1994, 6, (1), 73-76.

4. Franco, R.; Ferre, S.; Agnati, L.; Torvinen, M.; Gines, S.; Hillion, J.; Casado, V.; Lledo, P.; Zoli, M.; Lluis, C.; Fuxe, K. Evidence for adenosine/dopamine receptor interactions: indications for heteromerization. Neuropsychopharmacology 2000, 23, (4 Suppl), S50-59.

5. Torvinen, M.; Gines, S.; Hillion, J.; Latini, S.; Canals, M.; Ciruela, F.; Bordoni, F.; Staines, W.; Pedata, F.; Agnati, L. F.; Lluis, C.; Franco, R.; Ferre, S.; Fuxe, K. Interactions among adenosine deaminase, adenosine $\mathrm{A}(1)$ receptors and dopamine $\mathrm{D}(1)$ receptors in stably cotransfected fibroblast cells and neurons. Neuroscience 2002, 113, (3), 709-719.

6. Fuxe, K.; Marcellino, D.; Genedani, S.; Agnati, L. Adenosine A(2A) receptors, dopamine D(2) receptors and their interactions in Parkinson's disease. Mov. Disord. 2007, 22, (14), 1990-2017.

7. Fuxe, K.; Canals, M.; Torvinen, M.; Marcellino, D.; Terasmaa, A.; Genedani, S.; Leo, G.; Guidolin, D.; Diaz-Cabiale, Z.; Rivera, A.; Lundstrom, L.; Langel, U.; Narvaez, J.; Tanganelli, S.; Lluis, C.; Ferre, S.; Woods, A.; Franco, R.; Agnati, L.F. Intramembrane receptor-receptor interactions: a novel principle in molecular medicine. J. Neural. Transm. 2007, 114, (1), 49-75.

8. Franco, R.; Lluis, C.; Canela, E.I.; Mallol, J.; Agnati, L.; Casado, V.; Ciruela, F.; Ferre, S.; Fuxe, K. Receptor-receptor interactions involving adenosine A1 or dopamine D1 receptors and accessory proteins. J. Neural. Transm. 2007, 114, (1), 93-104.

9. Wood, P.L.; Kim, H.S.; Boyar, W.C.; Hutchison, A. Inhibition of nigrostriatal release of dopamine in the rat by adenosine receptor agonists: A1 receptor mediation. Neuropharmacology 1989, 28, (1), 21-25.

10. Ballarin, M.; Reiriz, J.; Ambrosio, S.; Mahy, N. Effect of locally infused 2-chloroadenosine, an A1 receptor agonist, on spontaneous and evoked dopamine release in rat neostriatum. Neurosci. Lett. 1995, 185, (1), 29-32.

11. Quarta, D.; Ferre, S.; Solinas, M.; You, Z.B.; Hockemeyer, J.; Popoli, P.; Goldberg, S.R. Opposite modulatory roles for adenosine $\mathrm{A} 1$ and $\mathrm{A} 2 \mathrm{~A}$ receptors on glutamate and dopamine release in the shell of the nucleus accumbens. Effects of chronic caffeine exposure. J. Neurochem. 2004, 88, (5), 1151-1158.

12. Quarta, D.; Borycz, J.; Solinas, M.; Patkar, K.; Hockemeyer, J.; Ciruela, F.; Lluis, C.; Franco, R.; Woods, A.S.; Goldberg, S.R.; Ferre, S. Adenosine receptor-mediated modulation of dopamine release in the nucleus accumbens depends on glutamate neurotransmission and N-methyl-Daspartate receptor stimulation. J. Neurochem. 2004, 91, (4), 873-880.

13. Jin, S.; Johansson, B.; Fredholm, B.B. Effects of adenosine A1 and A2 receptor activation on electrically evoked dopamine and acetylcholine release from rat striatal slices. J. Pharmacol. Exp. Ther. 1993, 267, (2), 801-808.

14. Okada, M.; Mizuno, K.; Kaneko, S. Adenosine A1 and A2 receptors modulate extracellular dopamine levels in rat striatum. Neurosci. Lett. 1996, 212, (1), 53-56.

15. Golembiowska, K.; Zylewska, A. Agonists of A1 and A2A adenosine receptors attenuate methamphetamine-induced overflow of dopamine in rat striatum. Brain Res. 1998, 806, (2), 202209. 
16. Yabuuchi, K.; Kuroiwa, M.; Shuto, T.; Sotogaku, N.; Snyder, G. L.; Higashi, H.; Tanaka, M.; Greengard, P.; Nishi, A. Role of adenosine A1 receptors in the modulation of dopamine D1 and adenosine A2A receptor signaling in the neostriatum. Neuroscience 2006, 141, (1), 19-25.

17. O'Neill, C.; Nolan, B.J.; Macari, A.; O'Boyle, K.M.; O'Connor, J.J. Adenosine A1 receptormediated inhibition of dopamine release from rat striatal slices is modulated by D1 dopamine receptors. Eur. J. Neurosci. 2007, 26, (12), 3421-3428.

18. Missale, C.; Nash, S.R.; Robinson, S.W.; Jaber, M.; Caron, M.G. Dopamine receptors: from structure to function. Physiol. Rev. 1998, 78, (1), 189-225.

19. Schoffelmeer, A.N.; Vanderschuren, L.J.; De Vries, T.J.; Hogenboom, F.; Wardeh, G.; Mulder, A. H. Synergistically interacting dopamine D1 and NMDA receptors mediate nonvesicular transporter-dependent GABA release from rat striatal medium spiny neurons. J. Neurosci. 2000, 20, (9), 3496-3503.

20. Tarazi, F.I.; Campbell, A.; Yeghiayan, S.K.; Baldessarini, R.J. Localization of ionotropic glutamate receptors in caudate-putamen and nucleus accumbens septi of rat brain: comparison of NMDA, AMPA, and kainate receptors. Synapse 1998, 30, (2), 227-235.

21. Ochi, M.; Inoue, H.; Koizumi, S.; Shibata, S.; Watanabe, S. Long-term enhancement of dopamine release by high frequency tetanic stimulation via a N-methyl-D-aspartate-receptor-mediated pathway in rat striatum. Neuroscience 1995, 66, (1), 29-36.

22. David, H.N.; Ansseau, M.; Abraini, J.H. Dopamine-glutamate reciprocal modulation of release and motor responses in the rat caudate-putamen and nucleus accumbens of "intact" animals. Brain Res. Brain Res. Rev. 2005, 50, (2), 336-360.

23. Iravani, M.M.; Kruk, Z.L. Real-time effects of N-methyl-D-aspartic acid on dopamine release in slices of rat caudate putamen: a study using fast cyclic voltammetry. J. Neurochem. 1996, 66, (3), 1076-1085.

24. Wu, Y.; Pearl, S.M.; Zigmond, M.J.; Michael, A.C. Inhibitory glutamatergic regulation of evoked dopamine release in striatum. Neuroscience 2000, 96, (1), 65-72.

25. McGinty, J.F. Regulation of neurotransmitter interactions in the ventral striatum. Ann. N.Y. Acad. Sci. 1999, 877, 129-139.

26. Bamford, N.S.; Zhang, H.; Schmitz, Y.; Wu, N.P.; Cepeda, C.; Levine, M.S.; Schmauss, C.; Zakharenko, S.S.; Zablow, L.; Sulzer, D. Heterosynaptic dopamine neurotransmission selects sets of corticostriatal terminals. Neuron. 2004, 42, (4), 653-663.

27. Ambrosio, A.F.; Malva, J.O.; Carvalho, A.P.; Carvalho, C.M. Modulation of Ca2+ channels by activation of adenosine A1 receptors in rat striatal glutamatergic nerve terminals. Neurosci. Lett. 1996, 220, (3), 163-166.

28. Huang, Q.; Zhou, D.; Chase, K.; Gusella, J.F.; Aronin, N.; DiFiglia, M. Immunohistochemical localization of the D1 dopamine receptor in rat brain reveals its axonal transport, pre- and postsynaptic localization, and prevalence in the basal ganglia, limbic system, and thalamic reticular nucleus. Proc. Natl. Acad. Sci. U.S.A. 1992, 89, (24), 11988-11992.

29. Le Moine, C.; Bloch, B. D1 and D2 dopamine receptor gene expression in the rat striatum: sensitive cRNA probes demonstrate prominent segregation of D1 and D2 mRNAs in distinct neuronal populations of the dorsal and ventral striatum. J. Comp. Neurol. 1995, 355, (3), 418-426. 
30. Limberger, N.; Spath, L.; Starke, K. A search for receptors modulating the release of gamma$[3 \mathrm{H}]$ aminobutyric acid in rabbit caudate nucleus slices. J. Neurochem. 1986, 46, (4), 1109-1117.

31. Floran, B.; Aceves, J.; Sierra, A.; Martinez-Fong, D. Activation of D1 dopamine receptors stimulates the release of GABA in the basal ganglia of the rat. Neurosci. Lett. 1990, 116, (1-2), 136-140.

32. Floran, B.; Gonzalez, B.; Floran, L.; Erlij, D.; Aceves, J. Interactions between adenosine A(2a) and dopamine D2 receptors in the control of $[(3) \mathrm{H}] \mathrm{GABA}$ release in the globus pallidus of the rat. Eur. J. Pharmacol. 2005, 520, (1-3), 43-50.

33. Harsing, L. G., Jr.; Zigmond, M. J., Influence of dopamine on GABA release in striatum: evidence for D1-D2 interactions and non-synaptic influences. Neuroscience 1997, 77, (2), 419-429.

34. Avshalumov, M.V.; Chen, B.T.; Marshall, S.P.; Pena, D.M.; Rice, M.E. Glutamate-dependent inhibition of dopamine release in striatum is mediated by a new diffusible messenger, $\mathrm{H} 2 \mathrm{O} 2$. $J$. Neurosci. 2003, 23, (7), 2744-2750.

35. Starr, M.S. GABA potentiates potassium-stimulated $3 \mathrm{H}$-dopamine release from slices of rat substantia nigra and corpus striatum. Eur. J. Pharmacol. 1978, 48, (3), 325-328.

36. Krebs, M.O.; Kemel, M.L.; Gauchy, C.; Desban, M.; Glowinski, J. Local GABAergic regulation of the N-methyl-D-aspartate-evoked release of dopamine is more prominent in striosomes than in matrix of the rat striatum. Neuroscience 1993, 57, (2), 249-260.

37. Ronken, E.; Mulder, A.H.; Schoffelmeer, A.N. Interacting presynaptic kappa-opioid and GABAA receptors modulate dopamine release from rat striatal synaptosomes. J. Neurochem. 1993, 61, (5), 1634-1639.

38. Blanchet, F.; Kemel, M.L.; Gauchy, C.; Desban, M.; Perez, S.; Glowinski, J. N-methyl-Daspartate-evoked release of $[3 \mathrm{H}]$ acetylcholine in striatal compartments of the rat: regulatory roles of dopamine and GABA. Neuroscience 1997, 81, (1), 113-127.

39. Cheramy, A.; Nieoullon, A.; Glowinski, J. Blockade of the picrotoxin-induced in vivo release of dopamine in the cat caudate nucleus by diazepam. Life Sci. 1977, 20, (5), 811-816.

40. Mayfield, R.D.; Jones, B.A.; Miller, H.A.; Simosky, J.K.; Larson, G.A.; Zahniser, N.R. Modulation of endogenous GABA release by an antagonistic adenosine A1/dopamineD1 receptor interaction in rat brain limbic regions but not basal ganglia. Synapse 1999, 33, (4), 274-281.

41. Armstrong-James, M.; Millar, J. Carbon fibre microelectrodes. J. Neurosci. Methods 1979, 1, (3), 279-287.

42. Palij, P.; Bull, D. R.; Sheehan, M. J.; Millar, J.; Stamford, J.; Kruk, Z. L.; Humphrey, P. P. Presynaptic regulation of dopamine release in corpus striatum monitored in vitro in real time by fast cyclic voltammetry. Brain Res. 1990, 509, (1), 172-174.

43. Millar, J.; Barnett, T.G. Basic instrumentation for fast cyclic voltammetry. J. Neurosci. Methods 1988, 25, (2), 91-95.

44. Kruk, Z.L.; O'Connor, J.J. Fast electrochemical studies in isolated tissues. Trends Pharmacol. Sci. 1995, 16, (5), 145-149.

45. Sidlo, Z.; Reggio, P.H.; Rice, M.E. Inhibition of striatal dopamine release by CB1 receptor activation requires nonsynaptic communication involving GABA, H2O2, and KATP channels. Neurochem. Int. 2008, 52, (1-2), 80-88. 
46. Limberger, N.; Trout, S.J.; Kruk, Z.L.; Starke, K. "Real time" measurement of endogenous dopamine release during short trains of pulses in slices of rat neostriatum and nucleus accumbens: role of autoinhibition. Naunyn. Schmiedebergs Arch. Pharmacol. 1991, 344, (6), 623-629.

47. Pazzagli, M.; Pedata, F.; Pepeu, G. Effect of K+ depolarization, tetrodotoxin, and NMDA receptor inhibition on extracellular adenosine levels in rat striatum. Eur. J. Pharmacol. 1993, 234, (1), 6165.

48. Chieng, B.; Bekkers, J.M. Inhibition of calcium channels by opioid- and adenosine-receptor agonists in neurons of the nucleus accumbens. Br. J. Pharmacol. 2001, 133, (3), 337-344.

49. Moore, K.A.; Nicoll, R.A.; Schmitz, D. Adenosine gates synaptic plasticity at hippocampal mossy fiber synapses. Proc. Natl. Acad. Sci. USA 2003, 100, (24), 14397-14402.

50. Sebastiao, A.M.; de Mendonca, A.; Moreira, T.; Ribeiro, J.A. Activation of synaptic NMDA receptors by action potential-dependent release of transmitter during hypoxia impairs recovery of synaptic transmission on reoxygenation. J. Neurosci. 2001, 21, (21), 8564-8571.

51. Zhang, H.; Sulzer, D. Glutamate spillover in the striatum depresses dopaminergic transmission by activating group I metabotropic glutamate receptors. J. Neurosci. 2003, 23, (33), 10585-10592.

52. DeBoer, P.; Westerink, B. H., GABAergic modulation of striatal cholinergic interneurons: an in vivo microdialysis study. J Neurochem 1994, 62, (1), 70-75.

53. Ikarashi, Y.; Yuzurihara, M.; Takahashi, A.; Hirohisa, I.; Shiobara, T.; Maruyama, Y. Modulation of acetylcholine release via GABAA and GABAB receptors in rat striatum. Brain Res. 1999, 816, (1), 238-240.

54. Shen, K.Z.; Johnson, S.W. Potentiation of GABA(A) receptor agonists by GABA uptake inhibitors in the rat ventral midbrain. Eur. J. Pharmacol. 2001, 428, (1), 1-7.

55. Fujiyama, F.; Fritschy, J. M.; Stephenson, F. A.; Bolam, J. P. Synaptic localization of GABA(A) receptor subunits in the striatum of the rat. J. Comp. Neurol. 2000, 416, (2), 158-172.

56. Zhang, W.; Yamada, M.; Gomeza, J.; Basile, A.S.; Wess, J. Multiple muscarinic acetylcholine receptor subtypes modulate striatal dopamine release, as studied with M1-M5 muscarinic receptor knock-out mice. J. Neurosci. 2002, 22, (15), 6347-6352.

57. Girault, J.A.; Spampinato, U.; Savaki, H.E.; Glowinski, J.; Besson, M.J. In vivo release of $[3 \mathrm{H}]$ gamma-aminobutyric acid in the rat neostriatum--I. Characterization and topographical heterogeneity of the effects of dopaminergic and cholinergic agents. Neuroscience 1986, 19, (4), 1101-1108.

58. Bracci, E.; Centonze, D.; Bernardi, G.; Calabresi, P. Dopamine excites fast-spiking interneurons in the striatum. J. Neurophysiol. 2002, 87, (4), 2190-2194.

(C) 2008 by the authors; licensee Molecular Diversity Preservation International, Basel, Switzerland. This article is an open-access article distributed under the terms and conditions of the Creative Commons Attribution license (http://creativecommons.org/licenses/by/3.0/). 